\title{
AIR POLLUTION IN KRAKOW - A GLANCE INTO THE FUTURE FROM A HISTORICAL PERSPECTIVE
}

DOI: https://doi.org/10.18509/AGB.2017.10

UDC: $502.3: 504.5(438)$

\author{
Wanda Wilczyńska-Michalik ${ }^{1}$, Marek Michalik ${ }^{2}$ \\ ${ }^{1}$ Institute of Geography, Pedagogical University of Cracow, Poland \\ ${ }^{2}$ Institute of Geological Sciences, Jagiellonian University, Poland \\ Corresponding author: wanda.michalik@ post.pl
}

Submitted: January 2017, Accepted: May 2017, Published: August 2017

\begin{abstract}
High concentrations of air pollution probably occurred in Krakow in the nineteenth and early twentieth centuries. Since the late 1960s due to the development of monitoring networks level of air pollution is well documented. In the past few decades, a considerable drop in $\mathrm{SO}_{2}$ concentration has been observed in conjunction with a major increase in the particulate matter and nitrogen oxides concentrations. The complex composition of aerosol particle samples (quartz, feldspars, clay minerals, carbonates, sulphates, chlorides, aluminosilicate and iron or iron oxide spherules of industrial origin and soot) suggests the multiplicity of their sources. In the near future, increased concentration of very fine particles and precursors of photochemical smog should be expected because of increasing emission from vehicle engines.
\end{abstract}

Key words: air pollution, smog, particulate matter (PM), soot, $\mathrm{SO}_{2}$

\section{Introduction}

High concentration of air pollution in Krakow is a problem of great concern. Concentration of particulate matter (PM), nitrogen oxides and benzo(a)pyrene locates Krakow among the most polluted cities in Europe [1]. Significant seasonal variation in respect to concentrations is noted, while strongly elevated values are recorded in winter months [2], [3]. Furthermore, diurnal variation is noted in cold seasons. This is related to the development of the inversion layer. In winter, such a phenomenon occurs almost daily and is long lasting.

High concentrations of air pollution probably occurred in Krakow in the nineteenth and early twentieth centuries, while systematic data have been collected since the late 1960s due to the development of monitoring networks.

\section{Air pollution in Krakow}

It is possible to assume that the high concentration of air pollution in Krakow was noted in the nineteenth and early twentieth centuries, being related to a rapid increase in the number of inhabitants and growth in industrial and artisanal production. Local meteorological conditions, localisation of the city in the Wisla river valley, high population density and urbanisation were the other important factors of high concentration of air pollution.

In the past few decades, significant change in the composition of air pollution was noted, that is, a considerable drop in $\mathrm{SO}_{2}$ concentration has been observed in conjunction with a major increase in the particulate matter and nitrogen oxides concentrations. Very high concentration of $\mathrm{SO}_{2}$ was related to industrial emission and also to the burning of coal for domestic heating. Reduction in the $\mathrm{SO}_{2}$ concentration was related to a significant lowering of industrial emissions in the 
early 1990s and a systematic decrease in the number of coal-fired furnaces in Krakow [4]. Recently, the concentration of $\mathrm{SO}_{2}$ in Krakow has fallen below the European Air Quality Standards. High concentration of airborne $\mathrm{SO}_{2}$ has been the reason for the high rate of erosion in Krakow's building stones, including those found in the most valuable historical monuments. Because of the high concentration of dissolved components in atmospheric precipitation, salt weathering was a dominant factor in the destruction of building stones [5], [6].

Recently, the most important components of air pollution in Krakow are PM, benzo(a)pyrene in PM, and nitrogen oxides. Detailed studies of single aerosol particles (particle size, morphology and chemical composition) using scanning electron microscope equipped with energy dispersive spectrometer indicate their very complex composition. Quartz, feldspars, clay minerals, carbonates, sulphates, and chlorides together with industrial products (aluminosilicate and iron or iron oxide spherules) commonly occur (Fig. 1, 2) [7]. Soot is present as individual particles (often nanoparticles) or as complex aggregates (Fig. 3, 4). Taking into account the number of particles in the samples (which correspond roughly with the number of particles in a cubic metre of air), soot is a very important component of aerosol. It dominates in PM2.5. It should also be added that PM is now enriched in the fine PM size fraction. The content of secondary aerosol particles is important, but the precise determination remains challenging (especially the content of secondary organic aerosol).

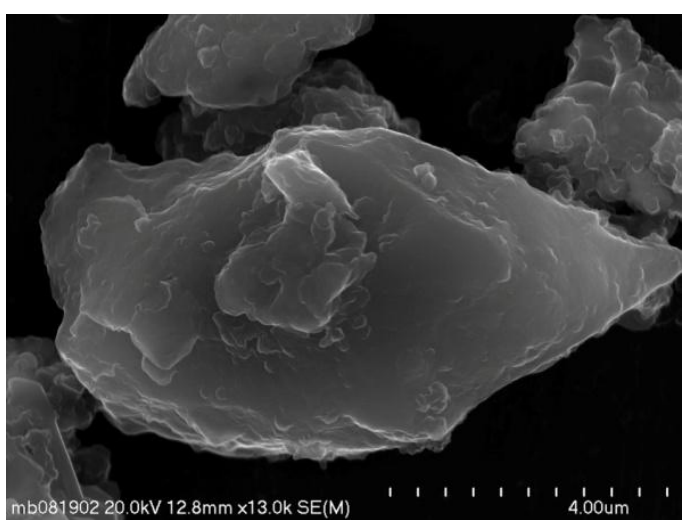

Figure 1: Quartz grain covered with clay minerals.
The complex composition of aerosol particle samples suggests the multiplicity of their sources.

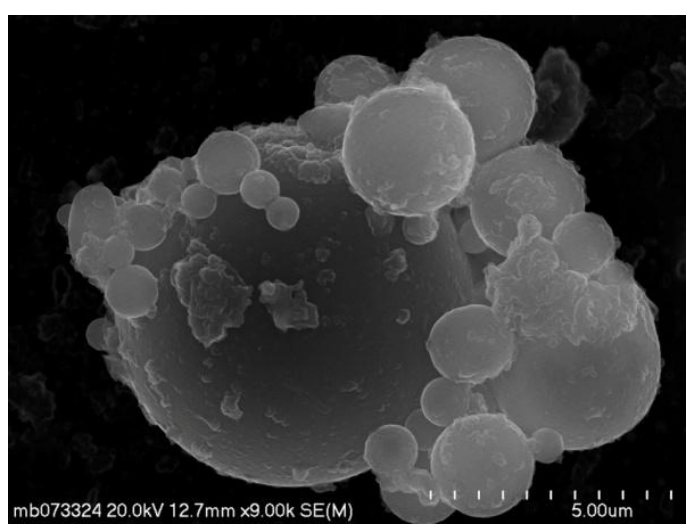

Figure 2: Aggregate of aluminosilicate spherical particles of industrial origin.

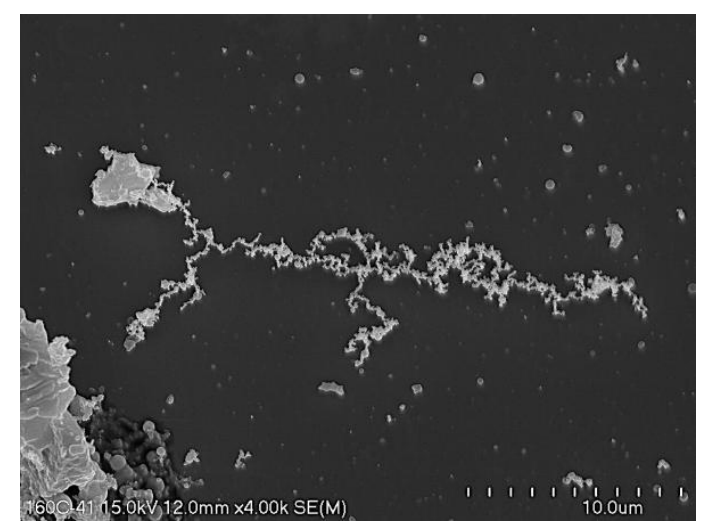

Figure 3: Elongated branched soot aggregate.

It is possible to distinguish particles of natural and anthropogenic origin, but the interpretation of their origin based on morphology and chemical composition is often inconclusive. Spherical particles typical of hightemperature industrial processes are relatively easy to identify, while the origin of the most abundant component of aerosols (at least taking into account the number of particles in the air volume), that is, the soot particles, is difficult to determine since particles of soot of various origins are similar in size and morphology [8]. 


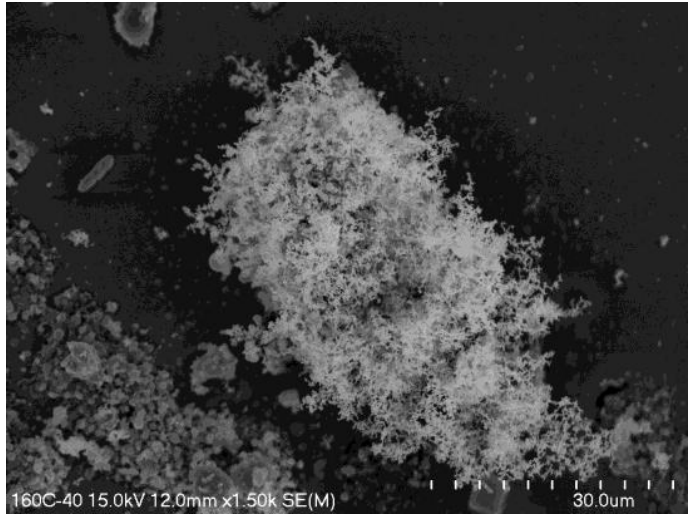

Figure 4: Densely packed soot aggregate.

It has to be noted that there are changes in the composition of aerosol particle assemblages over time because of the production and introduction of new technologies and materials. The occurrence of pigmentary $\mathrm{TiO}_{2}$ particles derived from building materials and paints currently noted in aerosol particles in Krakow can be presented as an example of such change [9].

Based on the results of our studies of aerosol particles and the evaluation of potential sources, it is possible to conclude that among numerous sources of air pollution the most important are vehicle emission; socalled low-emission, that is, related to household heating; emission from industrial plants and numerous small factories; resuspension from streets, construction and demolition sites; resuspension from soil; and dispersed plant debris. The level of recognition of the proportion in which each of these sources contributes is low. Published evaluations are based on modelling, but the scarcity of precise data related to emission (total emission and characteristics of emitted material) causes the low reliability of models.
High concentration of fine dust (containing mainly soot) makes the polluting material remarkably hazardous to human health. Concentration of PM2.5 varies from $48 \%$ to $80 \%$ of PM10, but is usually in the $60-80 \%$ range [10].

In the near future, increased concentration of very fine particles and precursors of photochemical smog should be expected because of increasing emission from vehicle engines. This coincides with modelling presenting the evolution of the characteristics of air pollution [11]. Increased concentration of fine or ultrafine particles could result in deteriorating health conditions for urban inhabitants, even in the case of decreased concentration of PM expressed in particle mass per volume $\left(\mu \mathrm{g} / \mathrm{m}^{3}\right)$.

\section{Concluding remarks}

Low level recognition of air pollution emitters and sources is the reason for the unsatisfactory results of action taken by the Krakow municipality in the case of air quality improvement. Evaluation of the threat posed to inhabitants is also missing. Single actions aimed at eliminating only selected sources merely postpone the full resolution and delay much expected improvement. Complex understanding of the issue and further studies are required, along with the full determination of government and awareness of society to improve the current situation. Also, legislation aimed at limiting traffic emission, the introduction of emission limits for coal, other fuels and boilers is required.

\section{References}

[1] Air quality in Europe - 2015 report. EEA Report, No 5/2015, pp 64, 2015.

[2] Raport o stanie środowiska naturalnego miasta Krakowa w latach 1994 - 1998. Stan aktualny $\mathrm{i}$ tendencje. Państwowa Inspekcja Ochrony Środowiska; Wojewódzki Inspektorat Ochrony Środowiska w Krakowie, Biblioteka Monitoringu Środowiska, Kraków, pp 1-73, 1999.

[3] Raport o stanie środowiska w województwie małopolskim w latach 2013 - 2015. Wojewódzki Inspektorat Ochrony Środowiska, Kraków, pp 1 - 120, 2016.

[4] Wilczyńska-Michalik W., Pietras B. \& Michalik M. Smog w Krakowie - spojrzenie w przyszłość z perspektywy historycznej. Aura, 2016, 11, pp 3-8, 2016. 
[5] Wilczyńska-Michalik W. Chemical composition of precipitation in Kraków; its role in the salt weathering of stone building materials. In: Stone Decay; Its Causes and Controls, Proceedings of the Conference "Weathering 2000", Belfast; Smith, B.J. and Turkington, A.V. (Eds.), pp 129 - 148, 2004.

[6] Wilczyńska-Michalik W. Influence of atmospheric pollution on the weathering of stones in Cracow monuments and rock outcrops in Cracow, Cracow-Częstochowa Upland and the Carpathians, Wydawnictwo Naukowe Akademii Pedagogicznej, pp 1-247, 2004.

[7] Wilczyńska-Michalik W. \& Michalik M. Skład i pochodzenie cząstek pyłów w powietrzu atmosferycznym w Krakowie. Aura, 3, pp 4-8, 2015.

[8] Michalik M., Brzeżański M., Wilczyńska-Michalik W., Fisior K., Klimas B., Samek L. \& Pietras B. Characterisation of solid particles emitted from diesel and petrol engines as a contribution to the determination of the origin of carbonaceous particles in urban aerosol. Scientific Conference on Automotive Vehicles and Combustion Engines (KONMOT 2016) IOP Publishing IOP Conf. Series: Materials Science and Engineering,148 (2016) 012079, 2016.

[9] Wilczyńska-Michalik W. Rzeźnikiewicz K., Pietras B. \& Michalik M. Fine and ultrafine $\mathrm{TiO}_{2}$ particles in aerosol in Kraków (Poland). Mineralogia, vol. 45, pp 65-77, 2015.

[10] Wilczyńska-Michalik W., Pietras B., Samek L., Furman L., Łatkiewicz A., Rzeźnikiewicz K. \& Michalik M. Submikronowe pyły w powietrzu atmosferycznym w Krakowie. Aura, 8, pp 4-7, 2015.

[11] Keogh D.U., Ferreira L. \& Morawska L. Development of a particle number and particle mass vehicle emissions inventory for an urban flee. Environmental Modelling and Software, vol. 24, pp 1323-1331, 2009. 